Z. klin. Chem. u. klin. Biochem.

9. Jg., S. $346-347$, Juli 1971

\title{
Mineral Changes in the Blood of Ovariectomized Mice after Treatment with $\beta$-Sitosterol
}

\author{
Biological Activity of Pbytoestrogens, IV.
} $\cdot 1$

\author{
By M. I. Elghamry, R. R. Hassanien and S. A. Elmovgy
} From the Faculty of Veterinary Medicine, Cairo University and Faculty of Veterinary Medicine
Ein Shams University, $U . A . R$.

(Eingegangen am 11. Dezember 1970)

Experiments were carried out in which ovariectomized mice were injected with increasing doses of $\beta$-sitosterol followed by quantitative determination of calcium, magnesium and phosphorus in the blood:

1. $\beta$-sitosterol in large doses $(25,50,75$ and $100 \mu \mathrm{g})$ significantly increased the calcium levels. Doses of 5 and $10 \mu \mathrm{g}$ had no effect.

2. Similar doses of the phytoestrogen induced a striking decrease in the magnesium concentrations which finally attained about half the control values.

3. Significant decreases in the level of phosphorus were evident after all dosage levels of $\beta$-sitosterol, except $100 \mu \mathrm{g}$, which caused only an insignificant reduction in the concentration of phosphorus.

Es werden Versuche an ovarektomierten Mäusen beschrieben, denen steigende Dosen $\beta$-Sitosterin injiziert wurden. Bestimmt wurden Calcium, Magriesium und Phosphor im Blut:

1. $\beta$-Sitosterin in hohen Dosen $(25,50,75$ und $100 \mu \mathrm{g})$ erhöhte den Calciumspiegel signifikant. Dosen von 5 und $10 \mu \mathrm{g}$ hatten keinen Effekt. 2. Gleiche Dosen des Phytoöstrogens führten zu einem deutlichen Abfall der Magnesiumkonzentration, der fast die Hälfte des Kontrollwertes erreichte.

3. Die Verminderungen des Phosphatspiegels waren bei allen verwendeten Dosierungen von $\beta$-Sitosterin signifikant, ausgenommen $100 \mu \mathrm{g}$, die einen nicht signifikanten Abfall der Phosphorkonzentration bewirkten.

The greatly increased interest in feeding research stems partly from the close relationship between inadequate nutrition and reproduction. The minerals, as indispenpensible elements in this situation, offer exciting possibilities for interference with the normal reproductive processes in farm animals $(1,2)$. KolB (3) gave special emphasis to calcium, magnesium and phosphorus which were apparently under hormonal control. Animal and synthetic estrogens were found to possess an essential regulating influence on the blood concentration of these minerals $(4,5)$. Although various plants represent a very important source of estrogens, no data are available about their effects upon mineral metabolism. Despite the intimate relation between these plant estrogens and reproduction (6), it is not known whether the disturbing action of phytoestrogens is related to any mineral changes in the blood. Therefore, in the present work, calcium, magnesium and phosphorus were measured in ovariectomized mice treated with $\beta$-sitosterol, which possesses a significant estrogenic activity (7).

\section{Materials and methods}

$\beta$-sitosterol (Koch-Light Ltd., England), a potent phytoestrogen, was prepared for experimental investigation by dissolving in ether and mixing with olive oil. After evaporation of the solvent, graded dilutions were prepared so that $0.1 \mathrm{ml}$ of the oil contained $5,10,25,50,75$ and $100 \mu \mathrm{g}$ of our estrogen-like compound. Bilateral ovariectomy was performed in 110 mature female mice (Charles River C. D. supplied from the Naval American Medical
Research Unit in Cairo) with an average body weight of 25-30 g. Two weeks after the operation, they were divided into 7 groups, the first of which contained 20 animals, injected with the oil to act as controls. The remaining 6 equal groups received subcutaneous injections of the required doses of $\beta$-sitosterol for 3 days. Twenty-four hours later, all the mice were slaughtered and the heparinized blood of each five animals was pooled and centrifuged at 3000 r. p. m. to separate the plasma. The latter was kept in a refrigetator until three estimations of each sample and four of the controls were carried out.

Calcium and magnesium were determined together by titration with EDTA (disodium ethylene diamino-tetra-acetic acid) at pH 10 in the presence of Eriochromblack $T$ (8). In the same 'manner, quantitative determination of calcium alone was performed by using murexide at $\mathrm{pH} 12$. The magnesium content was calculated by subtracting calcium from both $\mathrm{Ca}$ and $\mathrm{Mg}$. The inorganic phosphorus was determined by coupling with molybdate to form a yellow compound of phosphomolybdate (9). The latter was reduced by stannous chloride to give a blue colour of molybdenum blue which was compared with a standard curve made under similar conditions.

\section{Results and discussion}

Although the literature contains indications that plant estrogens affect animal reproduction, the role played by minerals in this phenomenon has not been investigated. The present study concerns the influence of physiologically important phytoestrogens on $\mathrm{Ca}, \mathrm{Mg}$ and $P$ as regulating factors for reproduction (10). In ovariectomized mice, these minerals underwent significant variations after treatment with $\beta$-sitosterol showing no linear correlation between the injected 
Table 1

Quantitative estimation of $\mathrm{Ca}, \mathrm{Mg}$ and $\mathrm{P}$ after graded doses of $\beta$ sitosterol

\begin{tabular}{|c|c|c|c|c|}
\hline $\begin{array}{l}\text { Gp. } \\
\text { no. }\end{array}$ & $\begin{array}{c}\text { Treatment } \\
(\mu \mathrm{g})\end{array}$ & $\begin{array}{c}\text { Minerals } \\
\text { calcium }\end{array}$ & $\underset{\text { magnesium }}{(\mathrm{mg} / 100 \mathrm{ml}}+$ & $\begin{array}{l}\text { S. E.) } \\
\text { phosphorus }\end{array}$ \\
\hline $\begin{array}{l}1 \\
2 \\
3 \\
4 \\
5 \\
6 \\
7\end{array}$ & $\begin{array}{r}0 \\
5 \\
10 \\
25 \\
50 \\
75 \\
100\end{array}$ & $\begin{array}{l}10.50 \pm 0.192 \\
10.80 \pm 0.400^{\mathrm{a}} \\
10.50 \pm 0.100 \mathrm{a} \\
11.60 \pm 0.224 \\
11.06 \pm 0.448 \\
11.53 \pm 0.308 \\
12.93 \pm 0.339\end{array}$ & $\begin{array}{l}4.65 \pm 0.082 \\
3.80 \pm 0.7 .00^{\mathrm{a}} \\
4.40 \pm 0.100^{\mathrm{a}} \\
3.80 \pm 0.100 \\
3.00 \pm 0.530 \\
2.80 \pm 0.100 \\
2.80 \pm 0.459\end{array}$ & $\begin{array}{l}4.10 \pm 0.252 \\
3.13 \pm 0.388 \\
3.20 \pm 0.000 \\
2.40 \pm 0.224 \\
2.93 \pm 0.490 \\
2.40 \pm 0.000 \\
3.86 \pm 0.3178\end{array}$ \\
\hline
\end{tabular}

$a=$ The differences between experimental and control animals are insignificant.

dose and their blood concentrations. The mineral changes, as shown in Table 1, are explained as follows.

\section{The calcium}

The levels of calcium in the blood were not affected after treatment with 5 and $10 \mu \mathrm{g}$ of $\beta$-sitosterol daily. With large doses $(25,50,75$ and $100 \mu \mathrm{g})$, calcium was slightly but significantly increased as compared to its concentrations in the control mice. The stimulatory effect of $\beta$-sitosterol on the blood content of calcium is consistent with that obtained by other estrogens in the earlier literature and which was first detected by RIDDLE and Dotrr (11). It is reasonable to assume that this action is due to a stimulated release of calcium from the bone into the circulation as indicated by hypo-ossification after estrogenic treatment (12), an action which may be mediated through the hypophysis (13). In this connection, the question arises as to whether the impaired reproduction represented by abortion is related to calcium concentration in the blood of farm animals. Hasselbach (14) indicated the importance of calcium in the induction of strong contraction of the uterus by activation of the energy-providing ATPase.

\section{The magnesium}

Small doses of $\beta$-sitosterol ( 5 and $10 \mu \mathrm{g}$ ) failed to induce significant changes in $\mathrm{Mg}$-levels when compared with the control values. Its concentrations were markedly decreased when the doses reached $25,50,75$ and $100 \mu \mathrm{g}$ daily. This fall may be attributed to increased deposition of magnesium in the liver and muscles which proved to contain higher amounts of the same mineral after estrogenic stimulation (15). This result suggests a new explanation for the possible interference of magnesium in the uterine inertia and dystocia which is usually noticed in farm animals after ingestion of estrogenic plants. Fraser (16) reported that this mineral is necessary for the pressor hormone to exert its oxytocic activity, and magnesium ions are also essential for the normal function of pregnant and nonpregnant myometrium (17).

\section{The phosphorus}

All the doses of $\beta$-sitosterol reduced significantly the phosphorus levels in the blood of treated animals except the highest one $(100 \mu \mathrm{g})$ which produced an insignificant decrease. There is at present no explanation for this result. It may be an indication of a reverse action which begins at this dosage level. The phosphorus reduction may reflect an enhanced rate of storage in some organs; e. g. the uterus (manuscript in preparation) and/or increased phosphorus utilization (18) in response to estrogenic stimulation. Also, there is the possibility that this effect on phosphorus may not be entirely due to enhancement of storage and utilization; the metabolic interrelation between different minerals may also play a significant role (19).

Finally, we would like to comment on the fact that the results of this study are of more than academic interest as they afford a new approach for the field of phytoestrogen research. This would focus light upon a possible relationship between the mineral metabolism in the body and the reproductive disturbances that occur in farm animals after ingestion of estrogenic plants.

\section{References}

1. Husslein, H. and E. Schüller, Arch. Gynäk. 187, 353 (1956). 2. UNDERWOOD, E. J., "Trace elements in human and animal nutrition". Academic Press Inc. Ltd., New York and London (1962). - 3. КоLв, E. „Uber den Einfluß von Oestrogenen auf den Gehalt des Blutes an Calcium, Magnesium und Phosphor"c. Dr. med. Vet. Thesis, München (1952). - 4. Dinusson, A., J. Animal Sci. 7, 523 (1948). - 5. BrügGemanN, J., K. Drepper, E. Kols and G. Schilpp, Zbl. vet. Med. 1, 233 (1954). - 6. Moule, G. R., A. W. H. Braden and D. R. Lamond, Animal Breed Abstr. 31, 139 (1963). - 7. ZAYED, S. M. A. D., A. Hassan and M. I. Elghamry, Zbl. vet. Med. 11, 476 (1964). - 8. BRUCKLY, E. S. Jr., J. G. Gibson and T. R. Bartolortr, J. Laborat. Clin. Med., S. Louis 38, 751 (1951). - 9. HoRwrtr, B. N., J. biol. Chemistry 199, 537 (1952). - 10. Brsschop, J. H. R. and J. W.
Groenwald, World Conf. Animal Prod., Roma, p. 47 (1963). 11. Riddie, O. and L. B. Dortr, Science 84, 557 (1936). - 12. Phillips, R. E., Turkey World 25, 11, 59, 60 (1950). - 13. Siefried, v. NidA and E. BrojA, Arch. Gynäk. 188, 247 (1957). 14. Hasselbach, W., Progr. Biophysics 14, 167 (1964). - 15. GüNther, Th. and Ch. Alter, this J. 5, 67 (1967). - 16. FRASER, A. M., J. Pharmacol. Exper. Therap., Baltimore 66, 85 (1939). - 17. Kumar, D., P. A. Zourlas and A. C. Barnes, Amer. J. Obstetr. Gynec. 86, 1036 (1936). - 18. WAKID, H. W. and D. M. Needham, J. Biophys. Biochem. Cytol. 10, 136 (1961). 19. Gresswelr, E. and D. Benzre, in Nutrition and Allied Sciences (cd. D. P. Cuthbertson) Oliver \& Boyd, Edinburgh and London, p. 249 (1963).
Prof. Dr. M. I. Elghamry, Faculty of Veterinary Medicine Cairo University

Giza U. A. R. 